\title{
OXIDATIVE STRESS IN HEMODIALYSIS PATIENTS: PATHOPHYSIOLOGICAL MECHANISMS, CLINICAL CONSEQUENCES AND BASIC PRINCIPLES OF TREATMENT \\ Svetlana Antić ${ }^{1}$, Nevena Draginić ${ }^{2}$, Tomislav Nikolić ${ }^{2,3}$, Nevena Jeremić ${ }^{2}$, Dejan Petrović ${ }^{2,3}$ \\ ${ }^{1}$ Clinic of Nephrology, Military Medical Academy Belgrade, Belgrade, Serbia \\ ${ }^{2}$ Faculty of Medical Sciences, University of Kragujevac, Kragujevac, Serbia \\ ${ }^{3}$ Clinic of Urology, Nephrology and Dialysis, Clinical Center Kragujevac, Kragujevac, Serbia
}

\author{
OKSIDATIVNI STRES KOD BOLESNIKA KOJI SE LEČE REDOVNOM \\ HEMODIJALIZOM: PATOFIZIOLOŠKI MEHANIZMI, KLINIČKE \\ POSLEDICE I OSNOVNI PRINCIPI LEČENJA \\ Svetlana Antić1, Nevena Draginić2, Tomislav Nikolić2,3, Nevena Jeremic2, Dejan Petrović2,3 \\ ${ }^{1}$ Klinika za nefrologiju, Vojnomedicinska akademija Beograd, Beograd, Srbija \\ ${ }^{2}$ Fakultet medicinskih nauka, Univerzitet u Kragujevcu, Kragujevac, Srbija \\ ${ }^{3}$ Klinika za urologiju, nefrologiju i dijalizu, KC Kragujevac, Kragujevac, Srbija
}

\begin{abstract}
Cardiovascular diseases are the leading cause of death in patients who undergo regular hemodialysis. Oxidative stress is a non-traditional risk factor for the development of cardiovascular diseases in this population of patients. It is defined as tissue damage caused by balance disturbance between the formation of free radicals and the function of protective antioxidative systems. The superoxide anion and hydrogen peroxide are precursors in the formation of stronger oxidants, such as: hydroxyl radical, peroxynitrite and hypochloric acid. Superoxide dismutase is the first line of antioxidant protection while catalase, glutathione peroxidase, trace elements, vitamin $C$, vitamin $E, N$-acetylcysteine and coenzyme Q10 also have a significant antioxidative role. Hemodialysis is itself a trigger for the increased formation of oxygen free radicals. The two main pathophysiological mechanisms of the increased formation of free oxygen radicals during the hemodialysis session are: bionicompatibility of the dialysis membrane and the presence of endotoxins in the hemodialysis solution. The measurement of myeloperoxidase concentration in a patient's serum during hemodialysis is an indicator of the severity of oxidative stress induced by the dialysis membrane (an indicator of the biocompatibility of the dialysis membrane). The main clinical consequences of oxidative stress include: atherosclerosis, erythropoietin resistance, malnutrition and amyloidosis associated with hemodialysis. The evaluation of oxidative stress in patients undergoing hemodialysis is performed by measuring the concentration of lipid peroxidation products (malonyldialdehyde, 4-hydroxynonenal, TBARS, F2-isoprostane, oxLDL), protein oxidation (AOPP), protein gelling (AGE), and oxidation of nucleic acids (8-OHdG). The antioxidant treatment strategy consists of replenishing vitamin $C$, vitamin $E$, selenium, $N$-acetylcysteine and coenzyme Q10. On-line hemodialysis, a biocompatible vitamin Ecoated dialysis membrane, an ultra-pure solution for hemodialysis, prevent oxidative stress, reduce the rate of cardiovascular morbidity and mortality and improve life quality of patients treated with regular hemodialysis.
\end{abstract}

Keywords: oxidative stress, hemodialysis, dialysis membrane, biocompatibility, hemodialysis solution, vitamin E, vitamin $C$.

\section{SAŽETAK}

Kardiovaskularne bolesti su vodeći uzrok smrti bolesnika koji se leče redovnom hemodijalizom. Oksidativni stres je netradicionalni faktor rizika za razvoj kardiovaskularnih bolesti u ovoj populaciji bolesnika. Definiše se kao oštećenje tkiva nastalo zbog poremećaja ravnoteže između stvaranja slobodnih radikala i funkcije zaštitinih antioksidativnih sistema. Superoksidni anjon i vodonik peroksid su prekursori za stvaranje jačih oksidanasa, kao što su: hidroksil radikali, peroksinitrit i hipohlorna kiselina. Superoksid dizmutaza je prva linija antioksidativne zaštite, a značajnu antioksdiativnu ulogu imaju i katalaza, glutation peroksidaza, elementi u tragu, vitamin $C$, vitamin $E, N$-acetilcistein koenzim Q10. Hemodijaliza je sama po sebi okidač za povećano stvaranje slobodnih radikala kiseonika. Dva glavna patofiziološka mehanizma povećanog stvaranja slobodnih radikala kiseonika u toku seanse hemodijalize su: bionikompatibilnost dijalizne membrane i prisustvo endotoksina u rastvoru za hemodijalizu. Merenje koncentracije mijeloperoksidaze u serumu bolesnika u toku seanse hemodijalize je pokazatelj težine oksidativnog stresa indukovanog dijaliznom membranom (pokazatelj biokompatibilnosti dijalizne membrane). U glavne kliničke posledice oksidativnog stresa spadaju: ateroskleroza, rezistencija na dejstvo eritropoetina, malnutricija i amiloidoza povezana sa hemodijalizom. Procena oksidativnog stresa kod bolesnika koji se leče hemodijalizom vrši se merenjem koncentracije produkata lipidne peroksidacije (malonyldialdehyde, 4-hydroxynonenal, TBARS, F2-isoprostanes, oxLDL), oksidacije proteina (AOPP), glikacije proteina (AGE) i oksidacije nukleinskih kiselina (8-OHdG). Antioksidativna strategija lečenja sastoji se u nadoknadi vitamina $C$, vitamina E, selena, $N$-acetilcisteina i koenzima Q10. On-line hemodijafiltracija, biokompatibilna dijalizna membrana obložena vitaminom E, ultračist rastvor za hemodijalizu sprečavaju oksidativni stres, smanjuju stopu kardiovaskularnog morbiditeta i mortaliteta i popravljaju kvalitet života bolesnika koji se leče redovnom hemodijalizom.

Ključne reči: oksidativni stres, hemodijaliza, dijalizna membrana, biokompatibilnost, rastvor za hemodijalizu, vitamin E, vitamin $C$

\section{sciendo}

DOI: 10.2478/sjecr-2019-0008
Corresponding author: Prof. Dejan Petrovic Faculty of Medical Sciences, University of Kragujevac, Kragujevac Clinic of Urology, Nephrology and Dialysis, Clinical Center Kragujevac, Kragujevac
ic68@sbb.rs 


\section{INTRODUCTION}

Cardiovascular diseases are the leading cause of death in patients on regular hemodialysis treatment (1). They are the leading cause of death of patients treated with kidney replacement methods. In this patient population, the prevalence of traditional and non-traditional risk factors for the development of cardiovascular diseases is high. Non-traditional risk factors include: anemia, inflammation, oxidative stress, hyperhomocysteinemia, hypervolemia, metabolism of calcium and phosphate, and lack of vitamin D $(1,2)$.

\section{Oxidative stress and pathophysiological mechanisms of its generation}

Oxidative stress is defined as organ damage caused by the balance disturbance between the formation of free radicals and the function of antioxidant systems $(3,4)$. A free radical is any atom or molecule with one or more unpaired electrons. The processes of protein, carbohydrate, lipid and nucleic acid oxidation cause damage to the structure and function of organ tissue cells $(3,4)$. Free oxygen radicals are produced in polymorphonuclear leukocytes under the action of NADPH (nicotinamide-adenindinukleotide-phosphate oxidase), which transforms the molecular oxygen into the superoxide anion $(3,4)$. The superoxide anion is transformed into hydrogen peroxide $\left(\mathrm{H}_{2} \mathrm{O}_{2}\right)$ under the action of superoxide dizmutase (SOD). The superoxide anion and hydrogen peroxide are precursors in the formation of stronger oxidants. The superoxide anion radical $\left(\mathrm{O}_{2}{ }^{-}\right)$reacts with nitric oxide (NO) and, in that case, toxic nitrogen products, such as peroxynitrite (ONOO-) (nitrosative stress), are formed (3). Hydrogen peroxide $\left(\mathrm{H}_{2} \mathrm{O}_{2}\right)$ reacts with intracellular iron $\left(\mathrm{Fe}^{2+}\right)$ forming the hydroxyl radical $\left(\mathrm{OH}^{-}\right)$, and that reaction is known as the Fenton reaction (classical oxidative stress) $(3,4)$. Within the Haber-Weiss reaction, the hydroxyl radical $\left(\mathrm{OH}^{-}\right)$is also generated by the interaction between the superoxide anion and hydrogen peroxide. Under the action of myeloperoxidase polymorphonuclear leukocytes (MPO), hydrogen peroxide is converted into hypochloric acid $\left(\mathrm{HOCl}^{-}\right)$in the presence of chlorine anions $\left(\mathrm{Cl}^{-}\right)$. Hypochloric acid can react with endogenous amines $\left(\mathrm{R}-\mathrm{NH}_{2}\right)$ causing the production of chloramines (RNH-Cl) (chlorinated stress) $(3,4)$. The natural antioxidant system consists of an enzyme and a non-enzymatic component. Superoxide dismutase (SOD) is a representative of the first line of the antioxidant system. It accelerates the degree of superoxide anhydration in hydrogen peroxide. Catalase (CAT) converts hydrogen peroxide into water, and this also works with glutathione peroxidase (GSH-Px), but in the presence of glutathione, a hydrogen source (3). The non-enzymatic components of defense include: vitamin $\mathrm{C}$, vitamin E, N-acetylcysteine, coenzyme Q10 $(3,4)$.

\section{Oxidative stress induced by dialysis}

Patients in the final stage of chronic kidney failure treated with hemodialysis exhibit increased free oxygen radicals levels due to prooxidative factors (age, diabetes mellitus, chronic inflammatory status, uraemia, bioincompatible dialysis membrane, presence of endotoxins in the hemodialysis solution) and the reduced activity of antioxidant mechanisms (lack of vitamin $\mathrm{C}$ and selenium, lack of vitamin E, reduced glutathione system activity) $(4,5)$.

Hemodialysis is itself a trigger for the increased formation of free oxygen radicals. The two major pathophysiological mechanisms for the increased formation of free oxygen radicals during the hemodialysis session are: bionicompatibility of the dialysis membrane and the presence of endotoxin in a hemodialysis solution $(4,5)$. Dialysis membranes play a central role in the hemodialysis and hemodynamic therapy process. They can be natural and artificial (synthetic). Natural membranes are cellulose derivatives, "lowflux", have low clearance of medium molecular weight uremic toxins and a lower degree of biocompatibility compared to synthetic membranes. Synthetic membranes (polysulphon, polyamide, polyacrylonitrile) are highly permeable ("highflux"), biocompatible, have good clearance of uremic toxins of medium molecular weight and are highly water-permeable (high coefficient for ultrafiltration - Kuf) $(6,7)$. The parameter for the evaluation of the efficiency of the dialysis membrane is the coefficient of mass transfer - KoA. It represents the product of the coefficient of transmission $(\mathrm{Ko})$ and the surface of the membrane (A). Depending on KoA dialysers can be: low-efficient dialysers KoA $<300$, moderately effective dialysers - KoA = 300-600 and high-efficiency dialysers - KoA > 600-700 (6, 7). The ultrafiltration capacity of the dialyser (provides clearance of uremic toxins of medium and high molecular weight) is quantified based on the ultrafiltration coefficient - Kuf. Depending on the ultrafiltration coefficient, the dialysers can be: "low-flux" (Kuf $<10 \mathrm{ml} / \mathrm{h} \mathrm{x}$ mmHg) and "high-flux" (Kuf $>20 \mathrm{ml} / \mathrm{h} \mathrm{x} \mathrm{mmHg)}(6,7)$. High-flux semipermeable dialysis membranes are used for on-line hemodialysis, with an ultrafiltration coefficient greater than $20 \mathrm{ml} / \mathrm{h}$ x mmHg ( $\geq 50 \mathrm{ml} / \mathrm{h}$ x mmHg, high water permeability and water-soluble secondary molecular weight substances) $(6,7)$. When the patient's blood is touched by the hemodialysis system, the complement and blood coagulation systems, platelets, mononuclear and polymorphonuclear cells of the immune system are activated, and can also signal hypersensitivity reactions $(6,7)$. During the hemodialysis session, due to direct contact of the blood and the surface of the membrane for hemodialysis, there is a direct activation of the polymorphonuclear leukocytes, which, due to activated myeloperoxidase (MPO), increase the free acidic radicals' levels [8]. The measurement of myeloperoxidase concentration released from the serum neutrophils during the hemodialysis is an indicator of the severity of oxidative stress induced by the use of membranes for hemodialysis of a different degree of bionicompatibility (8). Liquid that enters the dialyser is a combination of dialysis water and electrolyte solution and is called a dialysis solution (dialysate, dialysis fluid), and the fluid coming out of the dialyser is the combination of dialysis fluid and toxic molecules removed from the patient's blood $(9,10)$. Water mixed with electrolytic solution, with prior treatment in the water treatment system, is called dialysis water. During standard hemodialysis (3x weekly for $4 \mathrm{~h}$ ), the patient's organism is exposed to approximately 360 liters of dialysis solution. Therefore, high 
microbiological quality of the dialysis solution (ultra-pure dialysis solution) is required, and clinical trials show its beneficial effect on the outcome of the treatment of patients (9, 10). According to the European Best Practice Guidelines/European Renal Best Practice, ANSI/AAMI RD52 (American National Standards Institute/Association for the Advancement of Medical Instrumentation RD 52) and ANSI/AAMI/ISO 11663 for the Advancement of Medical Instrumentation ISO 11663), the ultra-pure dialysis solution is defined as a solution in which the number of colonies of bacteria is $<0.1 \mathrm{CFU} / \mathrm{mL}$ and the endotoxin concentration is $\mathrm{E}$ $<0.03 \mathrm{EU} / \mathrm{mL}$. The ultrafine solution is used for high-flux hemodialysis (HFHD) and hemodynamic filtration (HDF) (9, 10). For hemodialysis with the low-flux membrane (LFHD), according to current recommendations, the concentration of endotoxin should be $\leq 0.50 \mathrm{EU} / \mathrm{mL}(\leq 0.25 \mathrm{EU} / \mathrm{mL})$ and the number of colonies $\leq 100 \mathrm{CFU} / \mathrm{mL}(\leq 50 \mathrm{CFU} / \mathrm{mL})(9,10)$. Endotoxin and other bacterial products, backdiffusion/backfiltration processes, pass from a dialysis solution, through a dialysis membrane (pore size on the dialysis membrane, the ability of the membrane to adsorb endotoxins, the thickness of the membrane) into the patient's blood and activate the mononuclears and polimorfonuclears to produce free oxygen radicals and proinflammatory cytokines (interleukin-1, interleukin-6, tumor necrosis factor - TNF $\alpha$ ), all of which results in the development of oxidative stress, microinflammatory and accelerated atherosclerosis $(9,10)$. To detect bacterial products in a hemodialysis solution (dialysis), a biological assay of peripheral blood mononuclear cell induction is used to produce cytokines - PBMC (cytokine induction in peripheral blood mononuclear cells), and for the detection of lipopolysaccharide (LPS) and endotoxin, LAL (Limulus-amebocyte-lysate test) test $(9,10)$. Ultrapure dialysis solution prevents the development of oxidative stress, microinflamation, slows down the decrease in residual renal function of the kidney, improves the nutritional status of patients, increases the sensitivity of the red blood cell line to the effect of erythropoietin, reduces the cardiovascular morbidity and mortality of patients treated with regular dialysis $(9,10)$.

In patients treated with regular hemodialysis, the activity of enzymatic and non-enzymatic antioxidative systems is reduced. The decreased activity of antioxidant enzymes (superoxide dizmutase, glutathione peroxidase) is due to reduced concentration of trace elements, such as selenium, copper and zinc. Concentration of trace elements is reduced due to insufficient input, but also increased loss during hemodialysis session (11). Because of the lack of vitamin $C$ and vitamin $E$, the capacity of non-enzymatic antioxidative protection systems is reduced $(11,12)$.

\section{Clinical consequences of oxidative stress}

The main clinical consequences of oxidative stress include the development and acceleration of the atherosclerosis process, the development of anemia and the resistance to erythropoietin activity, malnutrition and amyloidosis associated with hemodialysis (13). The superoxide anion oxidizes tetrahydrobiopterin (an endogenous cofactor necessary for the activity of nitric oxide (NO) synthetase enzyme) and in this way reduces the production of NO. Nitric oxide is continuously produced in endothelial cells by the action of NO synthetase on L-arginine. It has a protective effect on the cardiovascular system (blocking the proliferation of vascular smooth muscle cells, platelet aggregability and adhesion of monocytes on endothelium). The activity of NO synthetase can be blocked by endogenous methylarginins. Asymmetric dimethylarginine is the most important endogenous blocking agent of the NO synthesis. It is mostly excreted through the kidneys, and partly under the influence of dimethyl-diaminohydrolase (DDAH), it is degraded to citrulline. Oxidative stress blocks the activity of DDAH, which reduces the degradation of asymmetric dimethylarginine, and its accumulation in endothelial cells blocks the nitric oxide synthase, which begins the process of atherosclerosis (13). Increased serum homocysteine concentration is another significant blocker of the activity of dimethyl-diamino-hydrolysis enzyme (DDAH) in endothelial cells of arterial blood vessels. Increased serum homocysteine concentrations are present in $80 \%$ of patients treated with regular hemodialysis. It is defined as the concentration of homocysteine in the serum higher than $15 \mu \mathrm{mol} / \mathrm{L}$ and is the result of a reduced activity of the enzymes crucial in the metabolism of homocysteine, such as the 5-methyltetrahydrofolate reductase, methionine synthase, and beta-synthesis of cystation. The decreased activity of these enzymes is due to the decreased concentration of vitamins B6, B12 and folic acid (cofacture of the enzymes mentioned) $(14,15)$. The lack of vitamin B6 occurs when the concentration of vitamin B6 in the serum is $<20 \mathrm{nmol} / \mathrm{L}$, the lack of vitamin B12 when the concentration of vitamin B12 in the serum is $<200 \mathrm{pg} / \mathrm{mL}$, and the lack of folic acid as the serum folate concentration is $<2.2 \mathrm{mg} / \mathrm{mL}(14,15)$. In healthy population, the normal concentration of ADMA in plasma is 1.0 $\mu \mathrm{mol} / \mathrm{L}$, in hemodialysis patients $2.2 \mu \mathrm{mol} / \mathrm{L}$, and at the concentrations of 3-15 $\mu \mathrm{mol} / \mathrm{L}$, ADMA blocks the formation of NO in the endothelial cells of the blood vessels and begins the atherosclerosis process (16). In addition to oxidative stress and hyperchomocysteinemia, a significant role in the development of atherosclerosis in patients treated with regular hemodialysis is the role of microinflammation. It is present in $30-50 \%$ of these patients and is defined as the concentration of C-reactive protein in the serum $\geq 10 \mathrm{mg} / \mathrm{L}$. A significant role in causing and maintaining chronic low-level microinflammation in this population of patients belongs to bio-compatibility of dialysis membrane, water quality for hemodialysis and vascular approach for hemodialysis (17-19). Microinflammation causes the accumulation of neutrophils and monocytes in the atherosclerotic plaque, and the release of free radicals of oxygen (oxidative stress), cytokines and metalloproteinases can lead to rupture of the atherosclerotic plaque cap and the development of acute coronary events (19, 20).

In $10-30 \%$ of patients treated with regular hemodialysis, there is a resistance to erythropoietin activity. According to the European recommendations, the resistance to erythropoietin activity is defined as the inability to achieve the target hemoglobin concentration in the blood $(\mathrm{Hb}=110-120 \mathrm{~g} / \mathrm{L})$ 
using erythropoietin at a dose of $\geq 300 \mathrm{IU} / \mathrm{kg} /$ week $(\geq 20.000$ IU/week) or darbepoetin-a at a dose of $\geq 1.5 \mu \mathrm{g} / \mathrm{kg} /$ week ( $\geq$ $100 \mu \mathrm{g} /$ week) or as a constant need for high doses of erythropoietin in order to maintain the target hemoglobin concentration (21). For the measurement of the severity of resistance to erythropoietin, the erythropoietin resistance index - ERI (Erythropoietin Resistance Index) is used (21). It represents the ratio of weekly dose of erythropoietin depending on body weight and blood hemoglobin (EPO/kg/weekly/Hb). Erythropoietin resistance index $\geq 0.02 \mu \mathrm{g} / \mathrm{kg} /$ week $/ \mathrm{g}$ of $\mathrm{Hb}$ indicates the presence of erythropoietin resistance (21). The main risk factors for the development of resistance to erythropoietin activity are iron deficiency, inflammation, oxidative stress, lack of vitamin D and secondary hyperparathyroidism, lack of vitamin C, vitamin B12, folic acid and L-carnitine, anti-EPO antibodies (21). Iron deficiency, oxidative stress, microinflammation and lack of vitamin $\mathrm{C}$ block the proliferation and differentiation of red cell precursor cells, reduce the synthesis of endogenous erythropoietin, stimulate the secretion of hepcidin and the development of a functional iron deficiency $(22,23)$.

\section{Parameters of oxidative stress in patients with hemodialysis}

Free oxygen radicals have a very short half-life (one second), so the clinical evaluation of oxidative stress is measured by measuring stable oxidation products. Oxidative stress parameters include lipid peroxidation products (such as: acrolein, malonyldialdehyde, 4-hydroxynonenal, TBARS, F2-isoprosthenes), lipid oxidation products (oxLDL, antioxLDL antibodies), oxidatively altered proteins (final product of protein oxidation - AOPP), final protein glycation products (AGE), evaluation of the activity of antioxidant enzymes (SOD and glutathione peroxidase in erythrocytes), evaluation of non-enzymatic anti-oxidants (plasma vitamin $\mathrm{C}$, glutathione and vitamin E content in erythrocytes) and inflammatory proteins CRP, albumin (23). 8-hydroxy-2'-deoxiguanosine (8-OHdG) is used as the parameter of nucleic acids oxidation, and its concentration in the serum and leukocytes is increased in patients treated with regular hemodialysis $(23,24)$.

\section{Treatment of oxidative stress in hemodialysis patients}

The antioxidant treatment strategy consists of the supplementation with vitamin $\mathrm{C}$, vitamin $\mathrm{E}$ ( $\alpha$-tocopherol), selenium, $\mathrm{N}$-acetylcysteine, and coenzyme Q10. Patients treated with regular hemodialysis have a deficiency of vitamin $C$ due to reduced dietary intake (fresh fruits and vegetables in addition to vitamin $\mathrm{C}$ also contain significant amounts of potassium) and its elimination during the hemodialysis session (low molecular weight $-\mathrm{MW}=176.1 \mathrm{Da}$, in a small percentage it is bound for plasma proteins - PB $=25 \%$, hydrosoluble vitamin) $(24,25)$. During the hemodialysis session, 100-300 mg of vitamin C is removed (vitamin C concentration after hemodialysis is reduced by $30-50 \%)(24,25)$. Normal serum vitamin $C$ concentration is $30-60 \mu \mathrm{mol} / \mathrm{L}$, and patients treated with regular hemodialysis often have a severe lack of vitamin $\mathrm{C}$ (vitamin $\mathrm{C}$ concentration in the serum $<10$ $\mu \mathrm{mol} / \mathrm{L})$ and require the substitution of this vitamin $(24,25)$. In patients treated with regular hemodialysis, vitamin $\mathrm{C}$ is administered per os at a dose of $100-200 \mathrm{mg} /$ day, and can also be applied i.v. at a dose of 300-500 mg after each hemodialysis session over a period of 8-12 weeks, with a defective monitoring for early detection of systemic oxalosis (measurement of serum oxalate concentration required) $(24,25)$. Intravenous use of vitamin $C$ reduces the concentration of ferritin and proinflammatory mediators in the serum, reduces oxidative stress and resistance to the effect of erythropoietin in patients on regular hemodialysis treatment $(24,25)$.

Vitamin E ( $\alpha$-tocopherol) has a very strong antioxidant effect. It is administered per os, and the dose of vitamin $\mathrm{E}$ can be expressed in international units or milligrams: $100 \mathrm{IU}=$ $67 \mathrm{mg}$ of natural vitamin $\mathrm{E}$ (26). When applied in a dose of $400-800 \mathrm{mg} /$ day over a period of 8-12 weeks it significantly reduces the concentration of malodialdehyde, oxLDL and TBARS in the plasma of patients treated with regular hemodialysis. The use of vitamin E reduces oxidative stress, prevents the development and acceleration of atherosclerosis and reduces the corpulence of intima-media of carotid arteries in the population of patients treated with regular hemodialysis (26).

$\mathrm{N}$-acetylcysteine (NAC) increases the production of glutathione, which plays an important role in the function of antioxidant enzymes, such as glutathione peroxidase (GSH-Px). Applied at a dose of 600-1200 mg/day for 3-6 months it significantly reduces the concentration of malondialdehyde (MDA) and asymmetric dimethylarginine (ADMA) in the plasma, reduces the resistance index to the effect of erythropoietin and compensates for the treatment of anemia in patients treated with regular hemodialysis $(23,26)$.

Coenzyme Q provides homeostasis of mitochondria and reduces oxidative stress (prevents oxidation of lipids, proteins, and nucleic acids). Applied in a dose of 1200-1800 mg daily for 4-6 months, it significantly reduces the concentration of final protein oxidation products (AOPP) and malondialdehyde (MDA) in the plasma of patients treated with regular hemodialysis $(26,27)$.

The choice of the modality of hemodialysis, the type of dialysis membrane and the type of solution for hemodialysis can significantly reduce oxidative stress, prevent the development of accelerated atherosclerosis, and correct the treatment of anemia in patients treated with hemodialysis (28-41).

On-line hemodiafiltration reduces the resistance to erythropoietin activity. The reduction of resistance to erythropoietin activity results from an increased removal of hepcidin, inflammatory mediators, and lipid, protein and nucleic acid oxidation products during a hemodynamic filtration session. Treatment on-line by hemodiafiltration over a period of three to six months significantly reduces inflammation, oxidative stress, serum hepcidin concentration, which increases the availability of iron for erythropoiesis and reduces the resistance to erythropoietin activity $(28,29)$. 
Vitamin E coated hemodialysis membranes reduce serum lipid peroxidation parameters such as malondialdehyde (MDA), thiobarbutyric acid reactive compounds (TBARS) and oxidized LDL cholesterol (oxLDL). Studies have shown that these membranes also reduce the concentration of oxidative nucleic acid parameters, such as 8-OHdG, as well as the concentration of microinflammatory parameters (CRP, interleukin-6) (30-37). Vitamin E coated dialysis membranes reduce the content of 8-OHdG in leukocytes in patients treated with regular hemodialysis (reduces DNA leukocyte oxidation). These membranes provide good control of the function of leukocytes, exhibit an antioxidant and antiinflammatory effect (30-37). The treatment of high-flux hemodialysis with polysulphonic membrane-bound vitamin E over a period of six months significantly reduces oxidative stress, microinflammation, an erythropoietin resistance index and corrects the treatment of anemia in patients treated with regular hemodialysis (30-37).

The treatment of anemia in patients on hemodialysis involves the use of erythropoiesis (ESA) stimulating agents and intravenous iron (iron sucrose). After the administration of intravenous iron at a dose of $100 \mathrm{mg}$ (within 15-30 minutes of infusion), the concentration of free oxygen radicals in these patients significantly increased (38-41). In order to prevent the development of oxidative stress after i.v., Ferrous Pyrophosphate Citrate (FPC) for adult patients treated with hemodialysis, administered through a solution for hemodialysis, was approved by the US Food and Drug Administration in 2015 (38-41). One $5 \mathrm{ml} \mathrm{FPC} \mathrm{(TrifericTM)} \mathrm{ampoule} \mathrm{is}$ added to every 2.5 gallons of bicarbonate concentrate so that the final FPC concentration in the hemodialysis solution is $110 \mu \mathrm{g} / \mathrm{L}(2.0 \mu \mathrm{mol} / \mathrm{L})$. FPC is used in every hemodialysis treatment, and the serum ferritin concentration and iron transfer (TSAT) saturation should be measured every three months. In patients with a serum ferritin concentration greater than $1000 \mathrm{ng} / \mathrm{mL}$, and TSAT greater than $50 \%$ should be discontinued, FCD should be used, standard bicarbonate solution for hemodialysis should be used. In patients whose serum ferritin concentration is less than $200 \mathrm{ng} / \mathrm{mL}$, i.v. iron 400-500 mg, during the next 4-5 hemodialysis treatments (100 mg/HD), and the FPC should be continuously applied. When the target serum ferritin concentration and saturated transfer of iron transfer is achieved, FPC should be applied continuously because 5-7 mg of iron (maintenance of target values of ferritin and TSAT) is lost during each hemodialysis session (38-41). Iron application through hemodialysis solution reduces oxidative stress and reduces the resistance to erythropoietin (dose of erythropoietin decreases by 35\%) (38-41).

\section{CONCLUSION}

Cardiovascular diseases are the leading cause of patients with chronic kidney disease treated with kidney replacement methods. In this patient population, there is a high prevalence of traditional but also new non-traditional risk factors for the development of cardiovascular diseases. Oxidative stress is a significant non-traditional risk factor for the progression of chronic kidney disease and the development of cardiovascular diseases in the population of patients on regular hemodialysis treatment. The main clinical effects of oxidative stress are: atherosclerosis, amyloidosis associated with hemodialysis, resistance to erythropoietin activity and malnutrition. The antioxidant treatment strategy consists of replenishing vitamin $\mathrm{C}$, vitamin $\mathrm{E}$, selenium, $\mathrm{N}$-acetylcysteine and coenzyme Q10. On-line hemodialysis, a biocompatible vitamin Ecoated dialysis membrane and an ultra-pure solution for hemodialysis prevent oxidative stress. Early detection of oxidative stress and timely application of appropriate antioxidant therapy can prevent the development of cardiovascular diseases, reduce the rate of cardiovascular morbidity and mortality, and improve the life quality of patients treated with renal replacement methods.

\section{ACKNOWLEDGMENTS}

Authors would like to express their deepest gratitude to the Ministry of Education, Science and Technological Development of the Republic of Serbia for the Grant N0175014 and also to the Faculty of Medical Sciences University of Kragujevac for their Junior Grant N002/19 from which the funds were used as one of the sources to financially support this paper.

\section{REFERENCES}

1. Cozzolino M, Mangano M, Stucchi A, et al. (2018). Cardiovascular disease in dialysis patients. Nephrol Dial Transplant. 33(1), 28-34. DOI: 10.1093/ndt/gfy174.

2. Zoccali C, Mallamaci F, Tripepi G. (2004). Novel Cardiovascular Risk Factors in End-Stage Renal Disease. J Am Soc Nephrol. 15(Suppl 1), 77-80. DOI: 10.1097/01.ASN.0000093240.84097.FE.

3. Locatelli F, Canaud B, Eckardt K-U, et al. (2003). Oxidative stress in end-stage renal disease: an emerging threat to patient outcome. Nephrol Dial Transplant. 18(7), 1272-80. DOI: 10.1093/ndt/gfg074.

4. Descamps-Latscha B, Drüeke T, Witko-Sarsat V. (2001). Dialysis-induced oxidative stress: biological aspects, clinical consequences, and therapy. Semin Dial. 14(3), 793-9. DOI: 10.1046/j.1525-139X.2001.00052.x.

5. Liakopoulos V, Roumeliotis S, Gorny X, et al. (2017). Oxidative Stress in Hemodialysis Patients: A Review of the Literature. Oxidative Med Cell Long. 2017: 3081856., DOI: 10.1155/2017/3081856.

6. Santoro A, Guadagni G. (2010). Dialysis membrane: from convection to adsorption. Nephrol Dial Transplant. 3(Suppl 1), 36-9. DOI: 10.1093/ndtplus/sfg035.

7. Ronco C, Clark W. Hemodialysis membranes. (2018). Nat Rev Nephrol. 14(6), 394-410. DOI: 10.1038/s41581-018-0002-x.

8. Wu CC, Chen JS, Wu WM, et al. (2005). Myeloperoxidase serves as a marker of oxidative stress during single hemodialysis session using two different biocompatible 
dialysis membranes. Nephrol Dial Transplant. 20(6), 1134-9. DOI: 10.1093/ndt/gfh764.

9. Ward RA. Ultrapure Dialysate. (2004). Semin Dial. 17(6), 489-97. DOI: 10.1111/j.08940959.2004.17617.x.

10. Glorieux G, Neirynck N, Veys N, et al. (2012). Dialysis water and fluid purity: more than endotoxin. Nephrol Dial Transplant. 27(11), 4010-21. DOI: 10.1093/ndt/gfs306.

11. Aziz MA, Majeed GH, Diab KS, et al. (2016). The association of oxidant-antioxidant status in patients with chronic renal failure. Ren Fail. 38(1), 20-6. DOI: 10.3109/0886022X.2015.1103654.

12. Handelman GJ. (2007). Vitamin C deficiency in dialysis patients - are we perceiving the tip of an iceberg? Nephrol Dial Transplant. 22(2), 328-31. DOI: 10.1093/ndt/gfl534.

13. Zalba G, Fortuño A, Diez J. (2006). Oxidative stress and atherosclerosis in early chronic kidney disease. Nephrol Dial Transplant. 21(10), 2686-90. DOI: 10.1093/ndt/gfl398.

14. Massy ZA. (2000). Importance of homocystein, lipoprotein (a) and non-classical cardiovascular risk factors (fibrinogen, and advanced glycation end-products) for atherogenesis in uraemic patients. Nephrol Dial Transplant. 15(Suppl 5), 81-91. DOI: 10.1093/ndt/15.suppl_5.81.

15. Culleton BF, Bostom AG. (2000). Hyperhomocysteinemia in chronic renal disease. In: Cardiovascular Disease in End-stage Renal Failure. Loscalzo J, London GM, (eds). The Oxford University Press, New York, 2000: 211-28.

16. Kielstein JT, Frölich JC, Haller H, et al. (2001). ADMA (asymmetric dimethylarginine): an atherosclerotic disease mediating agent in patient with renal disease? Nephrol Dial Transplant. 16(9), 1742-5. DOI: 10.1093/ndt/16.9.1742.

17. Lacson E, Levin NW. (2004). C-Reactive Protein and End-Stage Renal Disease. Semin Dial. 17(6), 438-48. DOI: 10.1111/j.0894-0959.2004.17604.x.

18. Petrović D, Obrenović R, Poskurica M, i ost. (2007). Povezanost C-reaktivnog proteina sa ehokardiografskim parametrima hipertrofije i ishemijske bolesti srca u bolesnika koji se leče ponavljanim hemodijalizama. Med Pregl. LX (Suppl 2), 160-4.

19. Akchurin OM, Kaskel F. (2015). Update on Inflammation in Chronic Kidney Disease. Blood Purif. 39(1), 8492. DOI: $10.1159 / 000368940$.

20. Koenig W. (2003). C-reactive protein and cardiovascular risk: an update on what is going on in cardiology. Nephrol Dial Transplant. 18(6), 1039-41. DOI: 10.1093/ndt/gfg103.

21. Kanbay M, Perazella MA, Kasapoglu B, et al. (2010). Erythropoiesis Stimulatory Agent-Resistant Anemia in Dialysis Patients: Review of Causes and Management. Blood Purif. 29(1), 1-12. DOI: 10.1159/000245041.

22. Locatelli F, Canaud B, Eckardt KU, et al. (2003). Oxidative stress in end-stage renal disease: an emerging threat to patient outcome. Nephrol Dial Transplant. 18(7), 1272-80. DOI: 10.1093/ndt/gfg074.
23. Liakopoulos V, Roumeliotis S, Zarogiannis S, et al. (2019). Oxidative stress in hemodialysis: Causative mechanisms, clinical implications, and possible therapeutic interventions. Semin Dial. 32(1), 58-71. DOI: 10.1111/sdi.12745.

24. Liakopoulos V, Roumeliotis S, Bozikas A, et al. (2019). Antioxidant Supplementation in Renal Replacement Therapy Patients: Is There Evidence? Oxidative Med Cell Long. 2019, Article ID 9109473, 23 pages. DOI: 10.1155/2019/9109473.

25. Zhang KY, Zuo L. (2014). Vitamin C supplementation in patients on maintenance dialysis. W J Clin Urol. 3(3), 344-50. DOI: 10.5410/wjcu.v3.i3.344.

26. Coombes JS, Fassett RG. (2012). Antioxidant therapy in hemodialysis patients: a systematic review. Kidney Int. 81(3), 233-46. DOI: 10.1038/ki.2011.341.

27. Gokbel H, Atalay H, Okudan N, et al (2011). Coenzyme Q10 and its Relation with Oxidant and Antioxidant System Markers in Patients with End-Stage Renal Disease. Ren Fail. 33(7), 677-81. DOI: 10.3109/0886022X.2011.589941.

28. Den Hoedt CH, Bots ML, Grooteman MPC, et al. (2014). Online hemodiafiltration reduces systemic inflammation compared to low-flux hemodialysis. Kidney Int 86(2), 423-32. DOI: 10.1038/ki.2014.9.

29. Panichi V, Scatena A, Rosati A, et al. (2015). High-volume online hemodiafiltration improves erythropoiesisstimulating agents (ESA) resistance in comparison with low-flux bicarbonate dialysis: results of the REDERT study. Nephrol Dial Transplant. 30(4): 682-9. DOI: 10.1093/ndt/gfu345.

30. Tarng DC, Huang TP, Liu TY, et al. (2000). Effect of vitamin E-bonded membrane on the 8-hydroxy 2,-deoxyguanosine level in leukocyte DNA of hemodialysis patients. Kidney Int. 58(2), 790-9. DOI: 10.1046/j.15231755.2000.00228.x.

31. Andrulli S, Di Fillipo S, Manzoni C, et al. (2010). Effect of synthetic vitamin E-bonded membrane on responsiveness to erythropoiesis-stimulating agents in hemodialysis patients: a pilot study. Nephron Clin Pract 115(1), 829. DOI: $10.1159 / 000294281$.

32. Panagiotou A, Nalesso F, Zanella M, et al. Antioxidant Dialytic Approach with Vitamin E-Coated Membranes. In: Ronco C, Rosner MH. Eds. Hemodialysis: New Methods and Future Technology. Contrib Nephrol. Basel, Karger, 2011; 171: 101-6.

33. Panichi V, Rosati A, Paoletti S, et al. (2011). A vitamin E-coated polysulphone membrane reduces serum levels of inflammatory markers and resistance to erythropoietin-stimulating agents in hemodialysis patients: results of a randomized cross-over multicenter trial. Blood $\mathrm{Pu}-$ rif. 32(1), 7-14. DOI: 10.1159/000321369.

34. Yang SK, Xiao L, Xu B, et al. (2014). Effects of vitamin E-coated dialyzer on oxidative stress and inflammation status in hemodialysis patients: a systematic review and meta-analysis. Ren Fail. 36(5), 722-31. DOI: 10.3109/0886022X.2014.890858. 
35. Yamadera S, Nakamura Y, Inagaki M, et al. (2017). Vitamin E-Coated Dialyzer Inhibits Oxidative Stress. Blood Purif. 44(4), 288-93. DOI: 10.1159/000478971.

36. D'Arrigo G, Baggetta R, Tripepi G, et al. (2017). Effects of vitamin E-Coated versus Conventiional Membranes in Chronic Hemodialysis Patients: A Systemic Review and Meta-Analysis. Blood Purif. 43(1-3), 101-22. DOI: 10.1159/000453444.

37. Locatelli F, Andrulli S, Vigano SM, et al. (2017). Evaluation of the Impact of a New Synthetic Vitamin EBonded Membrane on the Hypo-Responsiveness to the Erythropoietin Therapy in Hemodialysis Patients: A Multicenter Study. Blood Purif. 43(4), 338-45. DOI: 10.1159/000453442.

38. Fishbane S, Singh AK, Cournoyer SH, et al. (2015). Ferric pyrophosphate citrate (Triferic ${ }^{\mathrm{TM}}$ ) administration via the dialysate maintains hemoglobin and iron balance in chronic hemodialysis patients. Nephrol Dial Transplant. 30(12), 2019-26. DOI: 10.1093/ndt/gfv277.

39. Gupta A, Lin V, Guss C, et al. (2015). Ferric pyrophosphate citrate administered via dialysate reduces erythropoiesis-stimulating agent use and maintains hemoglobin in hemodialysis patients. Kidney Int. 88(5), 1187-94. DOI: 10.1038/ki.2015.203.

40. Shah HH, Hazzan AD, Fishbane S. (2016). Ferric Pyrophosphate Citrate: A Novel Iron Replacement Agent in Patients Undergoing Hemodialys. Semin Nephrol. 36(2), 124-9. DOI: 10.1016/j.semnephrol.2016.02.007.

41. Fishbane S, Shah HH. (2017). Ferric pyrophosphate citrate as an iron replacement agent for patients receiving hemodialysis. Hemodialysis Int. 21(Suppl 1), 104-9. DOI: $10.1111 /$ hdi.12554. 